\title{
Seroprevalence of Hepatitis B Surface Antigenaemia in Children in A Tertiary Health Institution In The Niger Delta Of Nigeria
}

\author{
*Alikor E. A. D. **Erhabor O. N. \\ ${ }^{*}$ Department Of Paediatrics, ${ }^{* *}$ Department of Haematology University of Port Harcourt Teaching Hospital, Port \\ Harcourt Nigeria
}

\begin{abstract}
Background: There is paucity of data on the seroprevalence of HBV infection in children living in urban areas of the Niger Delta of Nigeria. The aim of this study is to determine the seroprevalence of hepatitis $B$ surface antigenaemia among children presenting to the University of Port Harcourt Teaching Hospital (UPTH), to determine the trend in the seroprevalence of HBsAg over a five-year period and to correlate serological findings to clinical features.
\end{abstract}

Methods: Serum samples from 251 consecutively recruited children in UPTH aged $=16$ years were tested for Hepatitis $B$ surface antigen using Clinotech $\mathrm{HBsAg}$ kits and confirmed using the Trinity Biotec enzyme linked immunosorbent assay based HBsAg kits. Medical records of the children were also obtained.

Results: The overall prevalence of $\mathrm{HBsAg}$ among children tested was $12.4 \%$. HBsAg prevalence was highest in the 11-15 years age group (24.5\%) and the lowest in the 6 - 10 years age group (11.0\%). There was a statistically significant difference in the prevalence of HBV positivity based on age groups $(\div=8.47, p=0.014)$. Prevalence rate was relatively higher among males $(13.7 \%)$ compared to females (10.7\%). There is a statistically significant trend in the decline of $\mathrm{HBsAg}$ prevalence 1999 to $2004(\div$ for trend $=11.38, p=0.001$ ). The predominant symptoms among children positive for $\mathrm{HBs} A g$ were hepatosplenomegaly (75\%) and jaundice (64.5\%).

Conclusion: This study indicates a high prevalence of HBsAg among children presenting to a tertiary health facility in Port Harcourt.

Key Words: Seroprevalence, HBsAg, Paediatrics, Niger Delta, Nigeria.

\section{INTRODUCTION}

Hepatitis B virus (HBV) infection is a global public health problem and a significant cause of morbidity and mortality: Globally, more than 2 billion people have serological evidence of HBV infection and over 350 million are chronic carriers of the .virus. ${ }^{2,3}$
The prevalence of HBV infection varies greatly depending on the geographical region. In high endemicity regions particularly in developing countries, the prevalence is higher than $10 \%$ while in areas of intermediate endemicity the prevalence ranges between 2-10\%. ${ }^{4}$ In Southern and Eastern Asia, up to $50 \%$ of chronic HBV infection results from perinatal transmission from mother to child during or soon after birth. ${ }^{5}$ In some countries the use of a combined passive/active immunization strategy to prevent perinatal infection has dramatically reduced the incidence of chronic HBV infection, the incidence of primary hepatocellular carcinoma (PHCC) and cases of acute fulminant hepatitis B among children. ${ }^{6,7}$ In Nigeria, studies in adult population obtained prevalence of 7 $11 \%$ in blood donors and HIV-infected parients ${ }^{8,9}$ and $38 \%$ in patients with liver diseases. ${ }^{10}$ In some African studies high prevalence rates have been reported. ${ }^{11-13}$

There is paucity of data on the seroprevalence of HBV infection in children living in urban areas of the Niger Delta of Nigeria. The objective of this study is to determine the seroprevalence of HBV among children presenting to the University of Port Harcourt Teaching Hospital in the Niger Delta of Nigeria, and to examine the trend in the seroprevalence of HBsAg over a fiveyear period and to determine the association between HBsAg seroprevalence and the presenting symptoms and signs.

\section{MATERIALSAND METHOD}

The subjects for this study were 251 consecutivelyrecruited (and retrospectively studied) children less than 16 years old seen at the children department of the University of Port Harcourt Teaching Hospital, a five hundred-bed tertiary health facility in the cosmopolitan city of Port Harcourt., between $1^{\text {st }}$ January 1999 and $31^{\text {st }}$ December 2004. Subjects were in- and out-patients seen in the Hospital within the stated period in whom the clinicians have sufficient reason to suspect hepatitis $B$ and then request for screening. Demographic information about each child as well as history of HBV vaccination, history of blood transfusion and 
information on the clinical features presented by the subjects including presence of hepatosplenomegaly, jaundice, sickle cell disease, nephropathy, anaemia and malaria where extracted from the patients medical records. Informed consent were obtained from the parent or caregiver.

Venous blood samples were collected from all study subjects. Serum samples were separated and stored at $20^{\circ} \mathrm{C}$ prior to serological testing. All samples were screened using the commercially available Clinotech HBsAg kit (Clinotech Diagnostics, Canada), a one step hepatitis B surface antigen rapid chromatographic immunoassay test for the qualitative detection of hepatitis B surface antigen in serum. Initially reactive samples were confirmed using a second-generation Trinity Biotec enzyme-linked immmunosorbent assay (Trinity Biotec, Ireland).

\section{RESULTS}

A total of 251 children aged $0-16$ years (mean age $5.11 \pm$ 4.28 years) made up of 139 males and 112 females (M: $F=1.2: 1.0)$ constituted the subjects for this study. Thirty one children tested positive for HBsAg, giving an overall prevalence of Hepatitis B surface antigenaemia (HBsAg) of $12.4 \%$. The age distribution of $\mathrm{HBsAg}$ positivity is shown in figure I. HBsAg prevalence was highest in the $11-15$ years age group (24.5\%) and the lowest in the 6 10 years age group (11.0\%). There was a statistically significant difference in the prevalence of HBV positivity based on the various age groups $(\div=8.47, p=0.014)$. Nineteen out of the $139(13.7 \%)$ males in the study group tested positive for HBsAg compared to 12 out of the 112 females $(10.7 \%)$. This difference is not statistically significant $\left(\dot{\div}^{2}=0.26, p=0.607\right)$. The prevalence of HBsAg was higher among children that presented with hepatosplenomegaly, jaundice, nephropathy and sickle cell disease (Table 1). No case of HBV positivity was found among patients who presented with neonatal jaundice, human immunodeficiency virus (HIV) infection, pulmonary tuberculosis, persistent fever and septicemia. No patients had history of previous HBV vaccination. The trend of a decrease in HBsAg prevalence from 1999 to 2004 was statistically significant $(\div 2$ for trend $=11.83, p=$ $0.001)$. This is shown in figure 2.
Fig 1: Age distribution of $\mathrm{HBsAg}$ among the study group

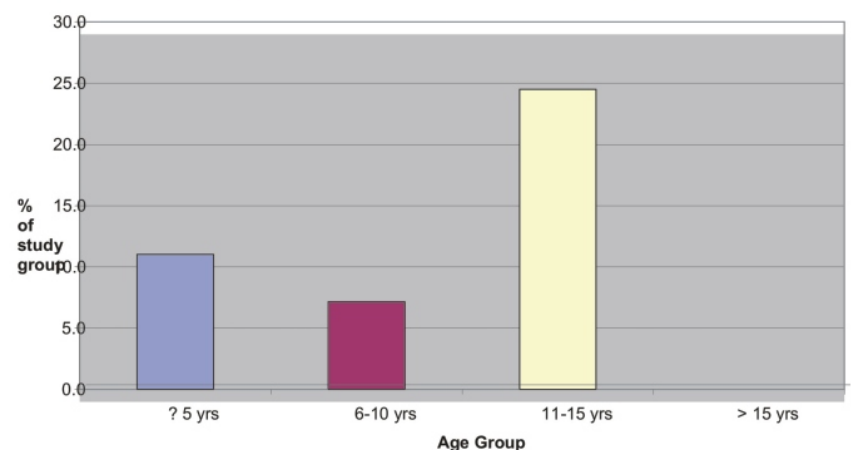

Fig 2: Trend in Prevalence of HBsAg in the study group

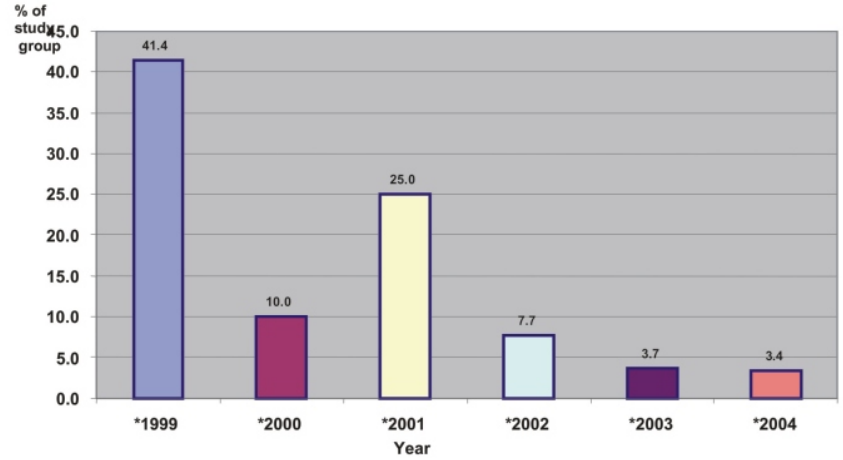

Table 1: Prevalence of HBsAg positivity among the study group based on presenting Clinical Features/Problems.

Clinical Features/Problems Number Screened Number HBsAg \% Positive positive

Hepatosplenomegaly

Jaundice(excluding

3

75.0

neonatal)

Sickle Cell Disease

Nephropathy

Ancmia

Malaria

Human immunodeficiency

virus/ AIDS

Neonatal jaundice

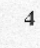

$62-20$

32.3

Tuberculosis

Septicaemia

Others

TOTAL

25.0

17.4

5.0

3.4

0.0

0.0

0.0

0.0

0.0

12.4

\section{DISCUSSION}

The overall prevalence of HBsAg among children less than 16 years of age in this study was $12.4 \%$. This prevalence value is consistent with the prevalence obtained in other hospital-based serological studies among hospitalized children in developing countries and higher than the figures obtained from more developed countries where universal vaccination againsthepatitis $B$ virus infection is available ${ }^{1220}$. 
This high prevalence obtained from the developing countries may partly be accounted for by the absence of universal vaccination program targeting this age group in these resource-limited countries. It may also result from the poor hygienic conditions in many African countries, facilitating horizontal transmission of hepatitis $B$ virus. Ear piercing, circumcision and scarification using nonsterilized instruments, all common high risk practices in the Niger Delta geopolitical zone of Nigeria, may also contribute to the observed high prevalence.

The observed decreasing trend in prevalence between 1999 and 2004 in this study may be as a result of the reintensified public health education in this era of HIVIAIDS. The increase in HBV prevalence from the age groups 6-10 years to $11-15$ years as observed in our study, which is consistent with result found in Turkish children, ${ }^{21}$ may have resulted from the increasing environmental exposure over time including crowded unhygienic conditions and possibility of transmission from mosquito bites. $^{12,}{ }^{22}$ This observation may also indicate that horizontal rather than vertical transmission may be the major mode of transmission. ${ }^{23}$ Unattended cuts and unhealed scars of family members and peers may become sources of infected serum and blood.

The high prevalence of HBsAg among children residing in the Niger Delta of Nigeria has enormous public health

\section{REFERENCE}

1. Kao JH, Hsu HM, Shaw WY, Chang MH, Chen DS. Universal hepatitis $B$ vaccination and decreased mortality from fulminant hepatitis infection in Taiwan. J Pediatr 2001; 139: 349-352.

2. Lee WM. Hepatitis B virus infection. N Engl J Med 1997; 337; 1733-1745.

3. Beasley RP, Hwang LY. Epidemiology of hepatocellular carcinoma. In Hoofnagle JH, (eds). Viral hepatitis and liver Disease. New York: Gruen and Stratton: 209-224.

4. Roychondhary A, Bhattachryya DK. Incidence of hepatitis B carriers in Calcutta, West Bengal. J Assoc Physicians India 1989; 37: 160.

5. Yao JL. Perinatal transmission of hepatitis B virus infection in China. Gut 1989; 38: 37-38.

6. Chang $\mathrm{MH}$, Chen $\mathrm{CJ}$, Lai MS, et al. Universal hepatitis B vaccination in Taiwan and the incidence of hepatocellular carcinoma in children. Taiwan Childhood hepatoma study group. NEngl J Med 1997; 336: 1855- 1859.

7. Huang K, Lin S. Nationwide vaccination: a success story in Taiwan. Vaccine 2000; 18: 35-38.

8. Durosinmi MA, Ndububa DA, Alabi O A et al. Prevalence of HIV infection and $\mathrm{HBsAg}$ in normal blood donors in lle - Ife, Nigeria. Niger Med J 1992; 21: 138-140.

9. Ejele O.A, Nwauche CA, Erhabor O. The prevalence of Hepatitis B surface antigenaemia in HIV- positive patients in the Niger Delta of Nigeria. Niger J Med 2004; 13; 175- 179. implications in terms of chronic HBV carriers rate (and consequent primary hepatocellular carcinoma) and HBV-induced chronic liver disease. ${ }^{24,25}$ As we did not study other hepatitis $B$ markers e.g. $\mathrm{HBe} \operatorname{lgM}, \mathrm{HBe}$ antigen, HBV DNA, the association between HBsAg and some clinical parameters eg hepatoslenomegaly, jaundice, cannot be concluded to be causal. Further study of this is recommended in our area.

Fortunately, mass HBV vaccination is being introduced in many parts of Nigeria. This has proven to be a successful method to control HBV infection in hyper endemic countries. ${ }^{9,26,27}$ We anticipate that these efforts will lead to a greater control of hepatitis B virus (HBV) infection and associated liver diseases.

In conclusion, the prevalence of HBsAg among children presenting to the University of Port Harcourt teaching hospital, Nigeria of whom HBsAg screening test was requested is high. There is a declining trend in the prevalence of HBsAg in these children between 1999 and 2004. Population-based studies in the Niger delta area and other parts of the country are recommended to determine the extent and scope of pediatric HBV infection in Nigeria. Mass vaccination, as is being introduced in Nigeria, raises hope of further decrease in prevalence of HBV. Intensive public education campaign against $\mathrm{HBV}$ is recommended.
10. Baba MM, Ajayi BB, Ekanem IA. Prevalence of hepatitis B surface antigen among patients suspected of liver diseases in a Nigerian hospital. Niger Postgrad Med J 2000; 7:91-95.

11. Vardas E, Mathai M, Blaauw D, McAnerney J, Coppin A, et al. Pre-immunization epidemiology of hepatitis $B$ virus infection in South African children. JMed Virol 1999; 58:111-115.

12. Abdool Karim SS, Coovadra HM, Windsol IM, et al. The prevalence and transmission of hepatitis $B$ virus infection in urban, rural and institutionalized black children of Natal/Kwazulu, South Africa. Int J Epidemiol 1988; 17:168173.

13. Martinson FE, Weigle KA, Mushahwar IK, et al. Seroepidemiological survey of hepatitis B and C virus infections in Ghanaian children. J Med Virol 1996; 48:278-283.

14. lancu L, Moraru E, Gotia S, et al. The prevalence of HBsAg in hospitalized children as a marker of hepatitis B virus infection. Bacteriol Virusol Parazitol Epidemiol 1997; 42(1-2): 95-98.

15. Kowalik- Mikolajewska $B$. Prognosis in acute viral hepatitis $B$ in children. Merkuriusz Lek 1996; 1(3): 185-186.

16. Akenami FO, Koskiniemi M, Ekanem EE, Bolarin DM, Vaheri A. Seroprevalence and co-prevalence of HIV and HBsAg in Nigerian children with and without protein energy malnutrition. Acta Trop 1997; 64(3-4): 167-174.

17. Nemba K, Babona DM, Vince JD. Age-specific prevalence of hepatitis B surface antigenaemia in hospitalized children at Port Moresby, Papua New Guinea (a cross-sectional study 
with implications for the Hepatitis B Control Programme). Ann Trop Pediatr 1993; 13(3): 237-241.

18. Meier C, Frey-Wettstein M. Hepatitis B antigen (HBsAg) in hospitalized children. Helv PaediatrActa 1997; 32(1): 11-19.

19. Golebiowska M, Badyra-Kowalik M, Kuchciak R. Asymptomatic $\mathrm{HBsAg}$ antigenaemia in children referred to hospital treatment for various reasons. Przegl Epidemiol 2003; 57(4): 619-624.

20. Cetinkaya F, Gurses N, Ozturk F. Hepatitis B seroprevalence among children in a Turkish hospital. J Hosp Infect 1995; 29(3): 217-219.

21. Ertekin V, Selimoglu MA, Altinkaynak S. Sero-epidemiology of hepatitis $B$ infection in an urban pediatric population in Turkey. Public Health 2003; 117:49-53.

22. Toukan AU, Sharaiha ZK, Abu-el-Rub OA, et al. The epidemiology of hepatitis virus among family members in the Middle East. Am J Epidermiol 1990; 132:220- 232.
23. Mocan H, Gedik Y, Okten A, Erduran E, Temiz I. Hepatitis B prevalence in Trabzon region. Trop J Med Sci 1994; 22:107109.

24. Yao GB. Importance of perinatal versus horizontal transmission of hepatitis B virus infection in China. Gut 1996; 38: $39-42$.

25. Al-Faleh FZ, Al- Jeffri M, Ramia S, et al. Sero-epidemiology of hepatitis B virus infection in Saudi Children 8 years after a mass hepatitis vaccination programme. J Infec 1999; 38: 16712.

26. Harpaz R, Mamahon BJ, Margolis HS, et al. Elimination of new chronic hepatitis $B$ virus infections: result of the Alaska immunization programme. J Infec Dis 2000; 181: 413-418.

27. Mahoney FJ, Wooddruff BA, Erben JJ, et al. Effect of Hepatitis $B$ vaccination programme on the prevalence of hepatitis $B$ virus infection. J Infec Dis 1993; 167: 203-207. 